\title{
Potential usage of the urban pruning residue for production of wood based panels
}

\section{Kelly Maria Zanuzzi PALHARINI ${ }^{1}$, José Benedito GUIMARÃES JUNIOR ${ }^{2}$, Douglas Lamounier FARIA², Rafael Farinassi MENDES², Thiago de Paula PROTÁSIO³ ${ }^{3}$ Lourival Marin MENDES²}

\author{
${ }^{1}$ Curso de Engenharia Florestal, Universidade Federal de Goiás, Jataí, GO, Brasil. \\ ${ }^{2}$ Programa de Pós-Graduação em Engenharia de Biomateriais, Universidade Federal de Lavras, Lavras, MG, Brasil. \\ ${ }^{3}$ Curso de Engenharia Florestal, Universidade Federal Rural da Amazônia, Parauapebas, PA, Brasil. \\ *E-mail: jbguimaraesjr@hotmail.com
}

Recebido em julho/2017; Aceito em dezembro/2017.

\begin{abstract}
The purpose of this paper was to verify the utilization potential of urban pruning residue from the woods of Licania tomentosa, Schinus molle and Tibouchina granulosa for the production of wood based panels. The materials were collected from the city of Jataí, Goiás, Brazil. The basic density and chemical analyses of these materials were evaluated. Subsequently, 3 wood based panels of each studied species were produced. The nominal density of these panels was of $0.60 \mathrm{~g} / \mathrm{cm}^{3}$, dimensions of $25 \times 25 \times 1.5 \mathrm{~cm}$. The adhesive used was urea formaldehyde at $8 \%$ based on its content of resinous solids. The pressing cycle used will be of nominal pressure of $4.0 \mathrm{MPa}$, temperature of $160{ }^{\circ} \mathrm{C}$ and time of 15 minutes. The absorption and thickness swelling properties after 2 and 24 hours of immersion in water, apparent density, perpendicular traction and flexural strength were evaluation. The design used was entirely randomized, using the Scott-Knott average test at $5 \%$ significance. It may be concluded that the materials used for production of the panels presented basic density and proper chemical analysis characteristics for the production of wood based panels. The residue which presented greatest potential of usage for production of wood based boards was the species Schinus molle. Palavras-chave: Schinus molle, Licania tomentosa, wood boards.
\end{abstract}

\section{Potencial de aproveitamento do resíduo da desrama urbana para produção de painéis aglomerados}

RESUMO: O objetivo deste trabalho foi verificar o potencial de utilização do resíduo da poda urbana das madeiras de Licania tomentosa, Schinus molle e Tibouchina granulosa para produção de painéis aglomerados. Os materiais foram coletados na cidade de Jataí, Goiás, Brasil. Avaliou-se a densidade básica e análise química destes materiais. Posteriormente foram produzidos 3 painéis aglomerados de cada espécie estudada. A densidade nominal destes painéis foi de $0,60 \mathrm{~g} / \mathrm{cm}^{3}$, dimensões de $25 \times 25 \times 1,5 \mathrm{~cm}$. O adesivo utilizado foi a uréia formaldeído a $8 \%$ com base no seu teor de sólidos resinosos. O ciclo de prensagem utilizado foi de pressão nominal de $4,0 \mathrm{MPa}$, temperatura de $160^{\circ} \mathrm{C}$ e tempo de 15 minutos. Avaliou-se as propriedades de absorção e inchamento em espessura após 2 e 24 horas de imersão em água, densidade aparente, tração perpendicular e flexão estática. O delineamento utilizado foi o inteiramente casualizado, com utilização do teste de médias de Scott-Knott a 5\% de significância. Pode-se concluir que os materiais utilizados para produção dos painéis apresentaram características de densidade básica e análise química adequada para a produção de painéis aglomerados. O resíduo que apresentou maior potencial de ser utilizado para produção de chapas aglomeradas foi a espécie Schinus molle.

Keywords: Schinus molle, Licania tomentosa, chapas de madeira.

\section{INTRODUCTION}

Arborization in urbanized areas offers a number of advantages, such as noise reduction, microclimate modifications, visual field change, wildlife habitat improvement, as well as urban recreation and leisure (CEMIG, 2011).

Most of the species used require periodic action of pruning its branches, especially to meet the characteristic requirements of the essences, on what concerns their development and longevity and ensure the safety in relation to electric power transmission cables (CHAHUD et al., 2012).

The material resulting from urban pruning is considered a residue, and may become a risk for the environment and society. As a consequence, their allocation on landfills results in extra costs for the cities, compromises large areas for disposal, increases the risk of fire in these landfills and wasteland, leads to landscape deterioration, air and water pollution (ROCHA et al., 2015).

Thus, one of the alternatives for the use of these residues is to use them as plywood panels. According to Iwakiri (2005), conventional wood based panels are a type of wood panel produced from particles of lignocellulosic materials; the adhesion between them occurs through a specific adhesive and under adequate conditions of pressure and temperature. This type of panel presents as one of its greatest advantages in relation to solid wood and even other panels, the possibility of using forest and agroindustrial residues as raw material for their confection (GUIMARÃES JUNIOR et 
al., 2011). These products are widely used by the furniture industry, civil construction and packaging industry.

Among the main tree species used for urban landscaping, we can highlight Licania tomentosa, Schinus molle and Tibouchina granulosa. According to Lorenzi, (2008) the species Licania tomentosa, belonging to the Chrysobalanaceae family, popularly known as Oiti, it is a heliophilous, evergreen, fruitful tree species, being typical of the Atlantic Forest region. The Schinus molle is a species of the Anacardiaceae family, popularly known as falso-chorão, aroeira, anacauita or aroeira-mansa, native of South America. Tibouchina granulosa is a plant of the Melastomataceae family, popularly known as quaresmeira, quaresmeira-roxa, quaresma, flor-da-quaresma, originated from the Atlantic Forest.

In this sense, the objective of this work was to verify the technical feasibility of producing wood based panels from urban pruning residues of the city of Jataí-GO, of the three most planted species, Licania tomentosa, Schinus molle and Tibouchina granulosa.

\section{MATERIAL AND METHODS}

In order to carry out this study, we used pruning woods of the three most planted tree species in the city of Jataí, located in the southwest of Goiás, at latitude $17^{\circ} 52$ '53" S and longitude $51^{\circ} 42^{\prime} 52^{\prime \prime} \mathrm{W}$, at the average altitude of 700 m. According to work by Barros et al. (2010) the most planted species in the region, in descending order, are Licania tomentosa, Schinus molle and Tibouchina granulosa. Figure 1 shows the three tree species used in this study.

The pruning branches of each species studied were randomly collected. After the collection, the discs were removed from them, for the performance of analysis and production of the panels.

The basic density was performed according to the Brazilian Technical Standards Association - ABNT NBR 7190/1997 (1997). For the determination of the chemical analysis of wood, the Brazilian Technical Association of Pulp and Paper - ABTCP (1974) and Tappi Test Method TAPI (1999) were used.

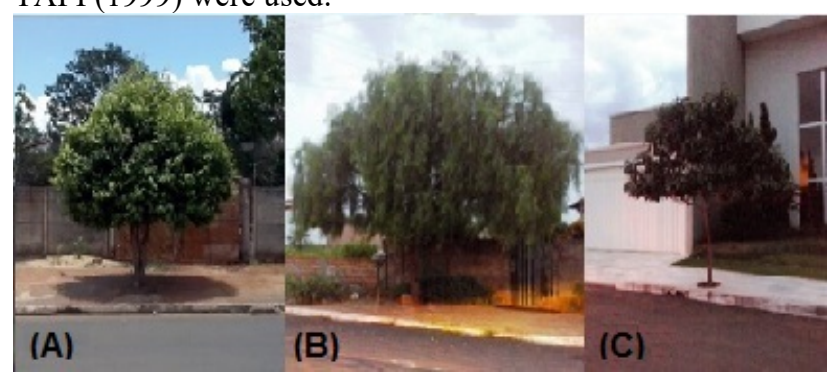

Figure 1. Tree species used in this study: (A) Licania tomentosa, (B) Schinus molle, and (C) Tibouchina granulosa.

Figura 1. Espécies arbóreas utilizadas neste estudo: (A) Licania tomentosa, (B) Schinus molle e (C) Tibouchina granulosa.

From the collection of the three studied species' branches, the wood was processed in a hammermill, being transformed into sliver-type particles. Subsequently, they were dried at $8 \%$ moisture on the dry basis and sieved.

The adhesive used was urea formaldehyde. The adhesive content of $8 \%$ was applied to the boards with respect to their solids content. The adhesive presented the following characteristics: $56.80 \%$ solids content, $8.75 \mathrm{pH}$, viscosity of $480 \mathrm{cP}$ and gelatinization time of 62 seconds.

The press cycle used was the nominal pressure of 4.0 $\mathrm{MPa}$, temperature of $160^{\circ} \mathrm{C}$ and a time of 15 minutes.

The nominal density of the boards was $0.60 \mathrm{~g} / \mathrm{cm}^{3}$. The dimensions of each panel were $250 \times 250 \mathrm{~mm} \times 15 \mathrm{~mm}$ in width, lenght and thickness, repectively.

The evaluated properties of these panels were absorption and swelling in thickness after 2 and 24 hours of immersion in water, density, perpendicular traction and static bending, taking as reference to the Brazilian Technical Standards Association - ABNT NBR 14810/2006 procedures (2006).

The outline used was completely randomized (DIC), considering the treatments as the different species. Treatment averages were compared by the Scott-Knott test at 5\% significance.

\section{RESULTS}

Table 1 presents the mean values of basic density of the three species of residue studied. It is possible to observe that the species Licania tomentosa showed a value of basic density superior to the two other species studied, presenting density of $0.58 \mathrm{~g} / \mathrm{cm}^{3}$. The species Schinus molle and Tibouchina granulosa had the same basic density, with mean values of $0.49 \mathrm{~g} / \mathrm{cm}^{3}$ and $0.48 \mathrm{~g} / \mathrm{cm}^{3}$, respectively.

Table 1. Mean values of basic density $\left(\mathrm{g} / \mathrm{cm}^{3}\right)$ of the woods from the species Licania tomentosa, Schinus molle and Tibouchina granulosa.

Tabela 1. Valores médios da densidade básica $\left(\mathrm{g} / \mathrm{cm}^{3}\right)$ das madeiras das espécies Licania tomentosa, Schinus molle e Tibouchina granulosa.

\begin{tabular}{lc}
\hline \multicolumn{1}{c}{ Species } & Basic density $\left(\mathrm{g} / \mathrm{cm}^{3}\right)$ \\
\hline Licania tomentosa & $0,58 \mathrm{~B}$ \\
Schinus molle & $0,49 \mathrm{~A}$ \\
Tibouchina granulosa & $0,48 \mathrm{~A}$ \\
\hline \multicolumn{1}{c}{ CV $(\%)$} & 7,53 \\
\hline
\end{tabular}

Means followed by the same letter do not differ from each other by the Scott-Knott test at a significance level of $5 \%$.

The chemical analysis of wood residues obtained by pruning is presented in Table 2. Note that for total extracts the Schinus molle species presented lower value; being a material with potential for the production of wood based panels.

Table 3 shows the average values of apparent density of the panels, absorption and swelling in thickness after 2 and 24 hours of immersion in water. For density, it was verified that there were no significant statistical differences between the panels studied. The density values were lower than the nominal $\left(0.60 \mathrm{~g} / \mathrm{cm}^{3}\right)$. This may be attributed to the specificity of the laboratory conditions in relation to the industrial process, with loss of materials during the handling of the particles in the steps of adhesive application, formation of the mattress and pressing of the panels. According to the rule CS 236-66 (1968) all panels produced were classified as low density.

Table 4 shows the mean values of the mechanical properties of the panels. It is observed, in a general manner, that the residue of Schinus molle presented superior mechanical properties in all evaluations. 
Table 2. Average values of extractives, lignin, ashes and holocellulose of the three species studied.

Tabela 2. Valores médios de extrativos, lignina, cinzas e holocelulose das três espécies estudadas.

\begin{tabular}{lcccc}
\hline Species & $\begin{array}{c}\text { Extractive } \\
(\%)\end{array}$ & $\begin{array}{c}\text { Lignin } \\
(\%)\end{array}$ & $\begin{array}{c}\text { Ashes } \\
(\%)\end{array}$ & $\begin{array}{c}\text { Holocellulose } \\
(\%)\end{array}$ \\
\hline L. tomentosa & $5,54 \mathrm{~B}$ & $30,89 \mathrm{~B}$ & $1,95 \mathrm{~B}$ & $61,62 \mathrm{~A}$ \\
S. molle & $2,90 \mathrm{~A}$ & $23,41 \mathrm{~A}$ & $0,73 \mathrm{~A}$ & $72,96 \mathrm{~B}$ \\
T. granulosa & $10,56 \mathrm{C}$ & $24,85 \mathrm{~A}$ & $0,64 \mathrm{~A}$ & $63,96 \mathrm{~A}$ \\
\hline CV $(\%)$ & 4,87 & 8,27 & 28,14 & 3,27 \\
\hline
\end{tabular}

Means followed by the same letter do not differ from each other by the Scott-Knott test at a significance level of $5 \%$. CV (\%) = Coefficient of variation.

Table 3.Mean values of the physical properties of the panels. Tabela 3. Valores médios das propriedades físicas dos painéis.

\begin{tabular}{lccccc}
\hline Species & $\begin{array}{c}\text { Density } \\
\left(\mathrm{g} / \mathrm{cm}^{3}\right)\end{array}$ & $\begin{array}{c}\text { AA2h } \\
(\%)\end{array}$ & $\begin{array}{c}\text { AA24h } \\
(\%)\end{array}$ & $\begin{array}{c}\text { IE2h } \\
(\%)\end{array}$ & $\begin{array}{c}\text { IE24h } \\
(\%)\end{array}$ \\
\hline L. tomentosa & $0,51 \mathrm{~A}$ & $43,64 \mathrm{~A}$ & $103,79 \mathrm{~A}$ & $4,54 \mathrm{~A}$ & $17,87 \mathrm{~A}$ \\
S. molle & $0,51 \mathrm{~A}$ & $45,28 \mathrm{~A}$ & $120,82 \mathrm{~B}$ & $7,38 \mathrm{~B}$ & $27,23 \mathrm{~B}$ \\
T. granulosa & $0,52 \mathrm{~A}$ & $73,88 \mathrm{~B}$ & $124,02 \mathrm{~B}$ & $9,29 \mathrm{~B}$ & $20,64 \mathrm{~B}$ \\
\hline CV $(\%)$ & 2,18 & 23,42 & 7,41 & 15,69 & 26,95 \\
\hline
\end{tabular}

Means followed by the same letter do not differ from each other by the Scott-Knott test at a significance level of $5 \%$. AA2h $=$ Absorption of water after 2 hours. AA24h $=$ Absorption of water after 24 hours. IE2h $=$ Swelling in thickness after 2 hours. IE24h = Swelling in thickness after 24 hours. CV $(\%)=$ Coefficient of variation.

Table 4. Mean values of the mechanical properties of the panels. Tabela 4. Valores médios das propriedades mecânicas dos painéis.

\begin{tabular}{lccc}
\hline \multicolumn{1}{c}{ Species } & MOR (MPa) & MOE (MPa) & TP $(\mathrm{MPa})$ \\
\hline L. tomentosa & $7,91 \mathrm{~A}$ & $2832,77 \mathrm{~B}$ & $0,1128 \mathrm{~A}$ \\
S. molle & $13,48 \mathrm{~B}$ & $2200,86 \mathrm{~B}$ & $0,1514 \mathrm{~B}$ \\
T. granulosa & $11,97 \mathrm{~B}$ & $1680,80 \mathrm{~A}$ & $0,1660 \mathrm{~B}$ \\
\hline \multicolumn{1}{c}{$\mathrm{CV}(\%)$} & 22,10 & 39,43 & 12.10 \\
\hline
\end{tabular}

Means followed by the same letter do not differ from each other by the Scott-Knott test at a significance level of $5 \% . \mathrm{MOR}=$ Modulus of rupture in static bending. $\mathrm{MOE}=$ Modulus of elasticity in static bending. $\mathrm{TP}=$ Perpendicular traction. CV $(\%)=$ Coefficient of variation.

\section{DISCUSSION}

According to the classification of the Technological Research Institute - IPT (1989), the pruning wood of the species Licania tomentosa was classified as medium basic density, while the Schinus molle and Tibouchina granulosa species were classified as low densification.

According to Iwakiri (2005) and Guimarães Júnior (2016), the wood density used for panel manufacture is a factor that directly influences the compression ratio, and therefore, for the fabrication of panels it is desirable that the basic density of the wood is low because they use a greater number of particles for a same compacted volume, thus increasing the compaction ratio which results in a better quality of the physical-mechanical properties of the panels.The compaction ratio (defined as the quotient of the specific mass of the panel by that of the wood) is another fundamental variable in the confection of the particulates and that disadvantages the physical properties, due to the greater amount of particles undergoing compression (SOUZA et al., 2012).

To Bila et al. (2016), a low value of extractives is a positive indicative for the manufacture of panels since woods with high extractive contents present difficulties of bonding, being able to alter the cure rate of the panel, as well as the appearance of bubbles in the press, resulting in low bond strength between the particles.
For the lignin analysis, the mean value obtained for Licania tomentosa was $30.89 \%$, presenting a statistical difference in relation to the two other species studied, Schinus molle and Tibouchina granulosa, which presented mean values of $23.41 \%$ and $24.85 \%$, respectively. Soares et al. (2017) reports that higher lignin values are desired since they tend to increase the cohesive and adhesion forces of the fibers, which improves the adhesiveness of the wood based panels.

The species Schinus molle and Tibouchina granulosa had a mean ash value of $0.73 \%$ and $0.64 \%$, respectively, statistically differing from the Licania tomentosa species, which had a mean ash value of $1.95 \%$. According to Tsoumis (1991), the ash content is generally between $0.2 \%$ and $1 \%$, thus, the ash content obtained from the species Licania tomentosa may be considered as high and the one from the other two species studied, Schinus molle and Tibouchina granulosa, as normal. According to Iwakiri (2005), ash values above $0.5 \%$ negatively interfere with the adhesiveness of the panel, as it affects its $\mathrm{pH}$ and also makes the material difficult to process, hence, all species may suffer interference for the manufacture of wood based panels, since all the species studied presented mean values of ash greater than $0.5 \%$.

For holocellulose values, the Schinus molle species presented a statistical difference of the other two species studied, with a mean value of $72.96 \%$, whereas the species Licania tomentosa and Tibouchina granulosa presented mean values of $61.62 \%$ and $63.96 \%$, respectively. Mejía-Díaz and Rutiaga-Quiñones (2008) found values close to those of this work for holocellulose for the wood of Schinus molle of $67.3 \%$. Thus, it is observed that the values found for holocellulose were close to those in the literature.

It can be noticed that the panels produced with Licania tomentosa were those that presented better dimensional stability, with lower values of water absorption and swelling in thickness. This phenomenon may have occurred due to this species presenting less amount of holocellulose. This macromolecule is the one that most contributes to increase the dimensional instability in the panels, due to the presence of a large number of free hydroxyls that can bind to water. This is due to the hydrophilic nature of cellulose and hemicellulose (JOHN, 2008).

According to Melo (2013), among these, hemicellulose is the most hydrophilic, and consequently the one that most contributes to dimensional changes.

Guimarães Junior et al. (2013), in a study on the effect of paraffin content on wood based panels made with Pinus oocarpa and $8 \%$ of the urea-formaldehyde adhesive, found for those panels which did not have paraffin applied, mean values of absorption after 2 hours of $116.1 \%$ and after 24 hours of $120.5 \%$. In this sense, the values observed for the pruning residue panels presented values close to those observed in the literature.

Carvalho et al. (2015) studying the use of residues of mate grass and pinus wood for the production of agglomerated panels, reported values for thickness ranging from $29.7 \%$ to $41.7 \%$, after 2 hours and from $39.80 \%$ and $52.10 \%$ after 24 hours. This way, it can be observed for this property that the panels produced with pruning residue presented lower values than the literature. 
The marketing standard CS 236-66 (1968) requires values for swelling in thickness, after 24 hours of immersion in water, of a maximum of $30 \%$ for low density panels. In this sense, all treatments are adequate in relation to the standardization.

It is observed for the modulus of rupture (MOR) that Schinus molle and Tibouchina granulosa presented higher values for this property. The results found in the present study were higher than those observed by Mendes et al. (2010) working with coffee husks in the proportions of 25,50 and $75 \%$, for the production of agglomerates, observed values ranging from 1.94 to $7.49 \mathrm{MPa}$.

All panels complied with the requirements of rule CS 236-66 (1968) which establishes minimum values for MOR of $5.50 \mathrm{MPa}$.

For the MOE, the highest value observed was for Licania tomentosa and Schinus molle. The results obtained in this study were superior to those presented by Battistelle et al. (2008), working with residue panels of sugarcane bagasse, finding values for this property varying between 998 and 1,662 and Pedrazzi et al. (2006), who found MOE values between $1014 \mathrm{MPa}$ and $1477 \mathrm{MPa}$, for treatment with $8 \%$ of adhesive, using sawdust of eucalyptus wood in the production of agglomerated panels.

This may have occurred due to the fact that it presents low amount of total extractives, which increases the quality of its bonding.

According to the marketing standard CS 236-66 (1968), the low density wood based panels produced with the ureaformaldehyde adhesive must have a minimum value for the modulus of elasticity of $1029.7 \mathrm{MPa}$. This way, it is verified that all the panels produced complied with said regulations.

For perpendicular traction it is noticed that the materials which presented better performance for this property were Schinus molle and Tibouchina granulosa. These results are close to those observed by Pedrazzi et al. (2006) working with the Eucalyptus saligna panel, this residual material being from the cellulose industry; finding values of 0.13 and $0.17 \mathrm{MPa}$.

The marketing standard CS 236-66 (1968) establishes a minimum value of $0.14 \mathrm{MPa}$ for perpendicular traction in low density panels and produced with urea-formaldehyde adhesive. In this sense, it is observed that only the panels produced with Licania tomentosa did not meet the normative requirement.

\section{CONCLUSIONS}

The materials used for production of the panels presented basic density and proper chemical analysis characteristics for the production of wood based panels. All the studied materials presented adequate dimensional stability according to regulations.

For MOE and MOR all the species presented potential of being used as wood based boards. For perpendicular traction however, only Licania tomentosa did not adequate to the normative.

In general, the residue which presented greatest potential of usage for production of wood based boards was the species Schinus molle.

\section{ACKNOWLEDGMENT \\ Fundação de Amparo a Pesquisa do Estado de Goiás and} CNPq.

\section{REFERENCES}

ASSOCIAÇÃO BRASILEIRA DE NORMAS TÉCNICAS (ABNT). NBR 14810: Chapas de madeira aglomerada. Rio de Janeiro: ABNT, 2006. 51 p.

ASSOCIAÇÃO BRASILEIRA DE NORMAS TÉCNICAS (ABNT). NBR 7190: Projetos de estruturas de madeira. Rio de Janeiro: ABNT, 1997. 107p.

ASSOCIAÇÃO BRASILEIRA TÉCNICA DE CELULOSE E PAPEL (ABTCP). Normas técnicas ABCP. São Paulo: ABTCP, 1974.

BARROS, E.F.S.; GUILHERME, F.A.G.; CARVALHO, R.S. Arborização urbana em quadras de diferentes padrões construtivos na cidade de Jataí. Árvore, Viçosa, v. 34 , n. 2, p. 287-295, 2010. DOI: http://dx.doi.org/10.1590/S0100-67622010000200011

BATTISTELlE, R. A.; RENOFIO, A. Caracterização física e mecânica de chapas de partículas homogêneas compostas do bagaço da cana e de folha caulinar. Revista Madeira Arquitetura \& Engenharia, Belo Horizonte, n. 23, ano 9, p. 92-201, 2008.

BILA, N. F.; IWAKIRI, S.; TRIANOSKI, R.; PRATA, J. G. Avaliação da qualidade de juntas coladas de seis espécies de madeiras tropicais da amazônia. Floresta, Curitiba, v. 46, n. 4, p. 455-464, 2016. DOI: http://dx.doi.org/10.5380/rf.v46i3.36311

CARVAlHO, A. G.; ANDRADE, B. G.; CABRAL, C. P. T.; VITAL, B. R. Efeito da adição de resíduos de poda da erva-mate em painéis aglomerados. Revista Árvore, Viçosa, v. 39, n. 1, p. 209-214, 2015. DOI: http://dx.doi.org/10.1590/0100-67622015000100020

CEMIG. Manual de arborização. Companhia Energética de Minas Gerais / Fundação Biodiversitas, 2011.

CHAHUD, E.; LAHR, F. A. R.; BLECHA, K. A.; NASCIMENTO, M. F.; BERTOLINI, M. S. Produção e avaliação do desempenho de painéis de partículas de madeira a partir de resíduos de podas de árvores urbanas. Revista Cultura e Extensão USP, São Paulo, v. 8, p. 109-122, $2012 . \quad$ DOI: http://dx.doi.org/10.11606/issn.2316-9060.v8i0p109-122

COMMERCIAL STANDARD. CS 236-66: mat formed wood particleboard. [S.1.], 1968.

GUIMARÃES JUNIOR, J. B.; MENDES, L. M.; MENDES, R. F.; MORI, F. A. Painéis de madeira aglomerada deresíduos da laminação de diferentes procedências de Eucalyptus grandis, Eucalyptus saligna e Eucalyptus cloeziana. Cerne, Lavras, v. 17, n. 4, p. 443-452, 2011. DOI: http://dx.doi.org/10.1590/S010477602011000400002 .

GUIMARÃES JUNIOR, J. B.; MENDES, L. M.; MENDES, R. F.; GUIMARÃES, B. M. R.; MELO, R. R. Efeito do teor da parafina nas propriedades físico-mecânicas de painéis aglomerados de pinus oocarpa. Ciência da Madeira, Pelotas, v. 4, n. 1, p. 72-82, 2013. DOI: http://dx.doi.org/10.12953/2177-6830.v04n01a06

GUIMARÃES JUNIOR, J. B.; XAVIER, M. M.; SANTOS, T. S.; PROTÁSIO, T. P.; MENDES, R. F.; MENDES, L. M. Inclusão de resíduo da cultura de sorgo em painéis aglomerados de eucalipto. Pesquisa Florestal Brasileira, Colombo, v. 36, n. 88, p. 435-442, 2016. DOI: http://dx.doi.org/10.4336/2016.pfb.36.88.1036

INSTITUTO DE PESQUISAS TECNOLÓGICAS. Fichas de características das madeiras brasileiras. 2. ed. São Paulo, 1989. 418p. 
IWAKIRI, S. Painéis de Madeira Reconstituída. Curitiba: Fundação de Pesquisas Florestais - FUPEF, Universidade Federal do Paraná, 2005.

JOHN, M. J.; SABU, T. Biofibres and biocomposites. Carbohydrate Polymers, v. 71, p. 343-364, 2008. DOI: https://doi.org/10.1016/j.carbpol.2007.05.040

LORENZI, H. Árvores brasileiras: manual de identificação e cultivo de plantas arbóreas nativas do Brasil. 5. ed. Nova Odessa: Instituto Plantarum, 2008. v.1.368p.

MEJÍA-DÍAZ, L. A.; RUTIAGA-QUIÑONES， J. G. Chemical composition of Schinus molle L. wood and kraft pulping process. Revista Mexicana de Ingeniería Química, v. 7, n. 2, p. 145-149, 2008.

MELO, R. R. Estabilidade dimensional de compostos de madeira. Ciência da Madeira, Pelotas, v. 4, n. 2, p. 152175, 2013. DOI: http://dx.doi.org/10.12953/21776830.v04n02a03

MENDES, R. F.; MENDES, L. M.; GUIMARÃES JUNIOR, J. B.; MOR, F. A.; CESAR, A. A. da S. Efeito da incorporação decasca de café nas propriedades físicomecânicas depainéis aglomerados de Eucalyptus urophylla S. T. Blake. Ciência e Agrotecnologia, Lavras, v. 34, n. 3, p. 610-617, 2010. DOI: http://dx.doi.org/10.1590/S1413-70542010000300012

PEDRAZZI, C.; HASELEIN, C. R.; SANTINI, E. J.; SCHNEIDER, P. R. Qualidade de chapas de partículas de madeira aglomerada fabricadas com resíduos de uma indústria de celulose. Ciência Florestal, Santa Maria, v. 16, n. 2, p. 201-212, 2006. DOI: http://dx.doi.org/10.5902/198050981899
ROCHA, A. J. F.; SOUZA, R. L. P.; REDA, A. L. L.; SILVA, G. T. Destinação sustentável do resíduo da poda de árvores urbanas. In: XV Safety, Health and Environment World Congress, XV, 2015. Anais... Porto, Portugal.

DOI: http://dx.doi.org/10.14684/SHEWC.15.2015.137-141

SOARES, S. S.; GUIMARÃES JÚNIOR, J. B.; MENDES, L. M.; MENDES, R. F.; PROTÁSIO, T. P.; LISBOA, F. J. N. Valorização do bagaço de cana-de açúcar na produção de painéisaglomerados de baixa densidade. Ciência da Madeira, Pelotas, v. 8, n. 2, p. 64-73,2017. DOI: http://dx.doi.org/10.12953/2177-6830/rcm.v8n2p64-73

SOUZA, K. B. Comparação das propriedades físicas de painéis aglomerados de Pinus de origem industrial e laboratorial. Scientia Plena, Aracaju, v. 8, n. 4, p. 1-5, 2012.

TAPPITEST METHODT222 om-88, Acidinsolublelignin in woodandpulp. In: Tappi Test Methods. Atlanta: Tappi Press, 1999.

TSOUMIS, G. Science andtechnologyofwood: structure, propertiesandutilization. New York: Chapman \& Hall, $1991.494 \mathrm{p}$. 